\title{
ALTERATIONS IN THE ANTIGENIC CONSTITUTION OF RENAL GLOMERULAR CAPILLARIES ACCOMPANYING THE HISTOLOGICAL MATURATION OF RENAL GLOMERULI IN THE RAT
}

\author{
BY \\ D. G. SCOTT AND N. R. ROWELL \\ Department of Dermatology, University of Leeds
}

Immunological studies of connective tissue have shown that, while there is an overlap in antigenic components between connective tissues throughout the body, this overlap is partial rather than complete. The different histological components of connective tissue tend to exhibit a degree of antigenic specificity. On the other hand, it has been found that histologically related tissues in the one species may show quantitative differences in their antigenic constitution and that tissues subserving similar physiological functions in different species may exhibit antigenic relationships which transcend species boundaries.

The basement membranes of renal glomerular capillaries and renal tubules have been found to contain common as well as unrelated antigens, and both these structures have been shown to be related immunologically to collagen (Goodman, Greenspon, and Krakower, 1955) and to argyrophilic reticulum (Taylor, Shepherd, and Robertson, 1961). The basement membranes of renal glomerular capillaries contain an additional group of antigens responsible for the production of nephrotoxic sera.

In their studies of nephrotoxic serum (NTS) antigens in canine renal glomeruli, Krakower and Greenspon (1954) found that an increase or decrease in glomerular capillary pressure was accompanied by a corresponding change in the concentration of NTS antigens. Constriction of the vena cava above the level of the renal veins, for example, led to an increase in the concentration of glomerular NTS antigens, whereas compensatory renal hypertrophy was accompanied by a decrease in the concentration of these antigens. Krakower and Greenspon also found that the NTS antigens were present in higher concentrations in the glomeruli of adult dogs than in those of neonatal dogs.

In later studies of the extra-renal distribution of the NTS antigens, Krakower and Greenspon (1958) produced strong evidence that these are present in varying concentration in capillaries throughout the body, and they showed that differences between the concentration of NTS antigens in different capillary beds can be related to the hydrostatic or filtration pressures to which capillaries in different locations are normally exposed. The concentration of NTS antigens in renal glomerular capillaries was found to be ten to twenty times greater than in the capillaries of the choroid plexus, forty times greater than in pulmonary capillaries, and twelve times greater than in capillaries of the ciliary processes. These obse? vations led to the suggestion that the NTS antigens might represent a chemical substance concerned the filtration or permeability properties of capillaries.

The proposition that NTS antigens serve as an index of the structural or functional adjustments of capillaries to different haemodyamic factors receives some support from the work of Markowitz (1960) and Simonsen (1953). These authors have shown that renal glomerular NTS antigens exhibit specificities which transcend species boundaries. Markowitz found that rabbit-anti-human glomerular basement membrane antisera, and sheep-anti-rabbit glomerular basement membrane antisera, after absorption with canine erythrocytes, mediated nephritis in dogs, and that sheep-anti-canine glomerular basement membrane antisera, absorbed 0 with rabbit erythrocytes, mediated nephritis in rabbits. Simonsen showed that duck anti-rabbit kidney and anti-dog kidney antisera were both $\underset{\sim}{\sim}$ equally effective for the mediation of nephritis in the o rabbit.

The fact that renal glomerular basement mem- No branes, in addition to NTS antigens, contain nonnephrotoxinogenic antigens-found also in the glomerular parietal capsule, renal tubular basement $\stackrel{2}{\mathbb{D}}$ membranes and collagen (Baxter and Goodman, $\stackrel{\infty}{+}$ 1956; Markowitz, 1960; Rothbard and Watson, 0 1961)-raises the possibility that the antigenic properties of renal glomerular capillaries reflect not 
only their structural differentiation but their functional differentiation also.

The present studies were undertaken to determine whether the histological differentiation of glomerular capillaries is accompanied by immunohistologically detectable changes in their antigenic properties. Frozen sections of kidney from adult, young, and embryonic rats were exposed to fluorescein-antiadult rat renal glomerulus and fluorescein-anti-adult rat splenic reticulum conjugates, before and after the absorption of these conjugates with embryonic connective tissue.

\section{Methods}

\section{Preparation of Antigens}

Antisera were raised in rabbits against renal glomeruli isolated, by methods based on those of Krakower and Greenspon (1951), from the kidneys of adult (2-monthold) rats. Antisera were also raised against adult rat splenic reticulum and against human renal connective tissue.

The splenic reticulum antigen represented the cell-free framework of the spleens of adult rats, freed of trabecular tissue and the larger blood vessels by passage through monel woven wire gauze sieves. For the preparation of the antigen, spleens were processed in batches of six. They were sectioned longitudinally into slices $3 \mathrm{~mm}$. thick. The slices were agitated vigorously in frequent changes of chilled $\left(4^{\circ} \mathrm{C}\right.$.) phosphate buffered saline $(0.05 \mathrm{M}$ phosphate $p \mathrm{H} \mathrm{8.6)}$, until they had been freed of cells. It was sometimes necessary to supplement agitation by cutting into islands of retained cells.

The white spongy cell-free splenic tissue was pressed gently through $50,80,100$, and 120 mesh sieves. Material passing through the 120 mesh sieve was fragmented in a glass tissue grinder, packed by centrifugation at $4^{\circ} \mathrm{C}$. and resuspended in buffered saline $(0 \cdot 01 \mathrm{M}$ phosphate $p \mathrm{H} \mathrm{7 \cdot 2}$ to $7 \cdot 4$ ) to give a 20 per cent. v/v suspension. The 20 per cent. suspension of splenic reticular tissue was stored in $1 \mathrm{ml}$. amounts at $-15^{\circ} \mathrm{C}$. until required.

The human kidney antigen was prepared from histologically normal human kidneys obtained at autopsy and stored at $-15^{\circ} \mathrm{C}$. For the preparation of the antigen, kidneys were finely sliced while still frozen. These slices were pressed through a 50 mesh sieve. Material passing this sieve was homogenized and passed successively through 80,100,120, and 140 mesh sieves. Material remaining on each sieve was harvested and rendered relatively free of cells by repeated homogenization and centrifugation. The cell-free fibrillar tissue so obtained was fragmented in a Griffith tube and packed by centrifugation and finally adjusted to a 40 per cent. v/v concentration in saline. Before use as an antigen, the renal connective tissue was enriched by the addition of an equal volume of a 40 per cent. suspension of isolated human renal glomeruli.

Relatively cell-free fibrillar tissue (embryonic connective tissue), derived from embryos measuring up to 1.0 $\mathrm{cm}$. in crown-to-rump length, was used for the prepara- tion of cross-absorbed conjugates. Embryos removed from the uterus and freed of placental membranes were quick-frozen in an alcohol- $\mathrm{CO}_{2}$ freezing mixture. Sections 10 to $20 \mu$ thick, cut from these embryos on a freezing microtome, were vigorously agitated in chilled buffered saline ( $0.05 \mathrm{M}$ phosphate $p \mathrm{H} \mathrm{8.6)}$. Agitation yielded three types of tissue:

(1) Fine fibrils suspended in the froth generated during agitation;

(2) Fibrillar and membranous material retained by 140 mesh sieves;

(3) Fibrils settling out of suspension over a period of $\frac{1}{2}$ to 1 hour at $4^{\circ} \mathrm{C}$.

These tissues were harvested in the order indicated, pooled, fragmented in a glass tissue grinder, and washed six times in $p \mathrm{H} 8.6$ buffered saline; finally the fragments were packed by centrifugation at 18,000 r.p.m. $(25,000$ R.C.F.). They were re-suspended in four volumes of $p \mathrm{H} 7 \cdot 2$ buffered saline $(0.01 \mathrm{M}$ phosphate) and stored at $-15^{\circ} \mathrm{C}$.

\section{Preparation of Antisera}

Antigens were injected into rabbits as a 10 per cent. $v / v$ suspension in saline and also as a water-in-oil emulsion in Freund's complete adjuvant. The antigen adjuvant emulsion contained: $5 \mathrm{ml}$. of a 20 per cent. $\mathrm{v} / \mathrm{v}$ suspension of antigen in saline; light liquid paraffin $4.25 \mathrm{ml}$.; Crill 19 (Croda Ltd., Snaith, Yorks.) $1.5 \mathrm{ml}$.; killed dried M. tuberculosis $2 \cdot 5 \mathrm{mg}$.

Two rabbits were used for the preparation of anti-adult rat renal glomerulus antisera and two for the preparation of anti-human kidney antisera. Animals immunized with the adult rat renal glomerular antigen received four courses of immunizing injections over a period of 8 months and those immunized with the anti-human kidney antigen a single course.

During a course of immunizing injections, animals received $2 \mathrm{ml}$. antigen in adjuvant and $4 \mathrm{ml}$. antigen in saline over a period of 1 month. The antigen-adjuvant emulsion was injected subcutaneously in $0.5 \mathrm{ml}$. amounts into each limb or into four separate sites on the back on a single occasion in the first week of a course. One week later the animals received the first of twelve intraperitoneal injections of antigen in saline. These were administered in $1 \mathrm{ml}$. amounts on 4 days of the week for 3 weeks.

The anti-adult rat splenic reticulin antisera used in the present experiments were obtained from two rabbits. Each animal had received two $2 \mathrm{ml}$. doses of antigen in adjuvant subcutaneously, the first 4 months before and the second 14 days before venepuncture.

\section{Fluorescein Conjugates}

The fluorescein-anti-adult rat renal glomerulus (FARG) conjugate was prepared from crude globulin fractions of antisera by the method of Marshall, Eveland, and Smith (1958). Fluorescein anti-adult rat splenic reticulum conjugate (F-ARS) was similarly prepared from pooled anti-splenic reticulum globulins. 
Conjugates were freed of non-specifically reacting material by passage down a column of Sephadex G25 and by absorption with guinea-pig liver powder; they were then absorbed with rat serum and erythrocytes. Finally a fraction of each conjugate was absorbed with onequarter of its own volume of packed homogenized human renal tissue $(F-A R G \times$ human and F-ARS $\times$ human conjugates). A second fraction of each conjugate was repeatedly absorbed with small (15 to $30 \mathrm{mg} . / \mathrm{ml}$.) amounts of fibrillar tissue obtained from rat embryos (F-ARG $\times$ embryo and F-ARS $\times$ embryo conjugates).

One of the purposes of the present experiments was to determine whether quantitative differences were detectable between the antigenic constitution of embryonic connective tissue on the one hand and adult splenic reticulum and renal glomeruli on the other. The process of cross-absorption was therefore followed immunohistologically and carried up to, but not beyond, the point ware the cross-absorbed conjugates were found to have lost their ability to produce detectable staining in the dermal connective tissues of $1.0 \mathrm{~cm}$. rat embryos.

\section{Preparation of Frozen Sections}

Unfixed frozen sections of kidneys from adult (2month-old), young (1 to 17-day-old), and $3 \cdot 0 \mathrm{~cm}$. embryonic rats were cut on a Reichert OmP freezing microtome incorporating a thermistor cold stage and the conventional knife cooling device. Sections were mounted in pairs on slides, dried in front of a fan, and washed in buffered saline $(0.05 \mathrm{M}$ phosphate $p \mathrm{H} \mathrm{8.6)}$ for three 10 -minute periods. They were then rinsed in distilled water and re-dried.

\section{Staining Experiments}

The present experiments involved the study of the specific staining produced in sections of the kidneys of young, embryonic, and adult rats after direct staining and cross-absorption experiments.

Direct staining experiments were based upon the use of the non-specifically absorbed F-ARG $\times$ human and F-ARS $\times$ human conjugates.

In cross-absorption experiments sections were exposed to the cross-absorbed F-ARG $\times$ embryo and F-ARS $\times$ embryo preparation.

In each case sections were pre-treated with a measured volume of unlabelled globulins from anti-human kidney antisera for 3 hours at room temperature and 15 hours at $4^{\circ} \mathrm{C}$. To the unlabelled globulin was then added its own volume of an anti-rat tissue conjugate and incubation was continued for a further $1 \frac{1}{2}$ hours.

Tests of specificity of staining were routinely run in parallel with direct staining and cross-absorption experiments. They were performed in the same way as these experiments, but involved the use of unlabelled anti-rat tissue globulins (ARK or ARS) in the place of the antihuman kidney globulins.

\section{Observations \\ Direct Staining Experiments}

The F-ARG $\times$ human and F-ARS $\times$ human $\frac{0}{6}$ conjugates produced specific staining in a variety of renal tissues (Table, opposite), including glomerular $\stackrel{\overrightarrow{+}}{\rightrightarrows}$ capillaries, the basement membrane of Bowman's capsule and of cortical and medullary tubules, and the media of arteries in the kidneys of rats of all ages. Eight of the twelve embryonic rat kidneys which were examined showed intertubular staining. In two cases this staining took the form of fine faintlystained fibrils. In the other instances patches of bright fluorescence were irregularly distributed in a faintly-stained matrix which was fenestrated by unstained spaces.

Interest in the present studies focused on the pattern of staining seen in renal glomeruli in sections from adult (2-month-old), young (7 to 17-day-old), neo-natal (1 to 6-day-old), and $3.0 \mathrm{~cm}$. embryonic rats.

Adult Rats.-Both the F-ARG $\times$ human and the F-ARS $\times$ human conjugates reacted with the capsular and capillary basement membranes in sections of kidney from adult rats. In these sec- $\vec{b}$ tions the glomerular tuft was seen as a comples? convolution of capillaries lying within a rought spherical space bounded by Bowman's membrares (Fig. 1).

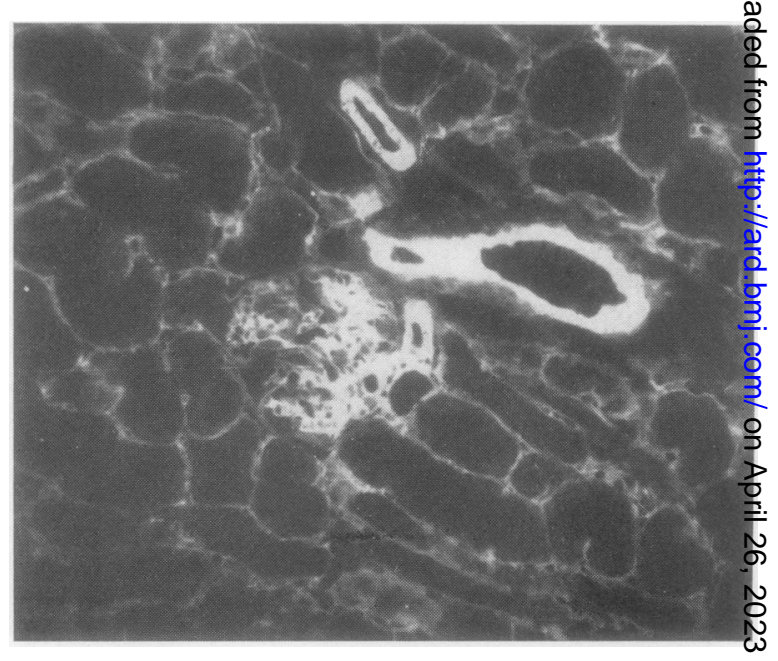

Fig. 1.-Adult rat kidney stained with the F-ARG $\times$ human conjugate. Specific staining in the renal glomerular capillary tufts, Bowman's membrane, the basement membranes of tubules, and arterial media. $\times 120$

Embryonic, Neo-natal, and Young Rats.-The 0 pattern of glomerular staining produced by the F-ARG $\times$ human conjugate in the kidneys of 
TABLE

DIRECT STAINING AND CROSS-ABSORPTION EXPERIMENTS

\begin{tabular}{|c|c|c|c|c|c|c|}
\hline \multirow{2}{*}{\multicolumn{2}{|c|}{ Renal Connective Tissue }} & \multirow[b]{2}{*}{ Rats } & \multicolumn{2}{|c|}{ Direct Staining } & \multicolumn{2}{|c|}{ Cross-Absorption } \\
\hline & & & $\begin{array}{c}\text { F-ARG } \\
\times \\
\text { Human } \\
\end{array}$ & $\begin{array}{c}\text { F-ARS } \\
\times \\
\text { Human } \\
\end{array}$ & $\begin{array}{c}\text { F-ARG } \\
\times \\
\text { Embryo } \\
\end{array}$ & $\begin{array}{r}\text { F-ARS } \\
\times \\
\text { Embryo } \\
\end{array}$ \\
\hline \multirow{4}{*}{ Capillary Basement Membranes } & \multirow[b]{2}{*}{ Fully developed glomeruli } & Adult & $\mathbf{B}$ & B & B & $\mathbf{W}$ \\
\hline & & $\begin{array}{l}\text { Young } \\
\text { New Born } \\
\text { Embryonic }\end{array}$ & $\mathbf{B}$ & B & $\mathbf{B}$ or $\mathbf{O}$ & $\mathbf{O}$ \\
\hline & Transitional glomeruli & $\begin{array}{l}\text { Young } \\
\text { New Born } \\
\text { Embryonic }\end{array}$ & B & B & $\mathbf{B}, \mathbf{W}$ or $\mathbf{O}$ & $\mathbf{O}$ \\
\hline & Newly developing glomeruli & $\begin{array}{l}\text { Young } \\
\text { New Born } \\
\text { Embryonic }\end{array}$ & B & B & $\mathbf{O}$ & $\mathbf{O}$ \\
\hline Inter-Capillary Staining & Newly developing glomeruli & $\begin{array}{l}\text { Young } \\
\text { New Born } \\
\text { Embryonic }\end{array}$ & $\mathbf{B}$ & B & $\mathbf{O}^{*}$ & $\mathbf{O}$ \\
\hline \multirow{4}{*}{ Bowman's Membrane } & \multirow{2}{*}{ Fully developed glomeruli } & Adult & $\mathbf{B}$ & B & b & $\mathbf{O}$ \\
\hline & & Others & $\mathbf{B}$ & B & $\mathbf{B}$ & $\mathbf{O}$ \\
\hline & Transitional glomeruli & $\begin{array}{l}\text { Young } \\
\text { New Born } \\
\text { Embryonic }\end{array}$ & B & B & B & $\mathbf{O}$ \\
\hline & Newly developing glomeruli & $\begin{array}{l}\text { Young } \\
\text { New Born } \\
\text { Embryonic }\end{array}$ & B & B & $\mathbf{B}$ & $\mathbf{O}$ \\
\hline \multirow{2}{*}{\multicolumn{2}{|c|}{ Tubular Basement Membranes }} & Adult & $\mathbf{B}$ & B & $\mathbf{W}$ & $\mathbf{O}$ \\
\hline & & $\begin{array}{l}\text { Young } \\
\text { New Born } \\
\text { Embryonic }\end{array}$ & B & $\mathbf{B}$ & b & $\mathbf{O}$ \\
\hline \multicolumn{2}{|l|}{ Peri-tubular Capillaries } & All & $\mathbf{B}$ & B & $\mathbf{O}$ & $\mathbf{O}$ \\
\hline \multicolumn{2}{|l|}{ Renal Interstitium } & Embryonic & B & $\mathbf{B}$ & $\mathbf{O}$ & $\mathbf{O}$ \\
\hline
\end{tabular}

Kidney sections from $3.0 \mathrm{~cm}$. rat embryos and from new born, young, and adult rats were treated with fluorescein-anti-adult rat renal glomerulus (F-ARG) or fluorescein-anti-adult rat splenic reticulum (F-ARS) conjugates which had been absorbed with connective tissue obtained from: $(a)$ human kidneys or $(b)$ rat embryos measuring up to $1.0 \mathrm{~cm}$. in crown-to-rump length. $\mathbf{B}=$ bright specific staining $B>b$. $\mathbf{W}=$ faint specific staining. $\mathbf{O}=$ no staining.

*Matrix material unstained. Specific staining distributed solely as streaks.

embryonic, neo-natal, and young rats did not differ from that produced by the F-ARS conjugate. Glomeruli seen in these kidneys could be classified as follows:

(1) Incompletely developed:

(a) Newly developing.

(b) Transitional.

(2) Fully developed.

In this classification, differentiation between (1) and (2) is based upon the histological appearances presented by Bowman's capsule. In (1), Bowman's capsule was seen as a crescentic tubule encircled by a specifically stained membrane. The concave aspect of the tubule usually showed an irregular digitate outline (Fig. 2, overleaf). In (2) the glomeruli possessed a definitive capsule lined by a specifically stained membrane (Fig. 3, overleaf).
NEWLY DEVELOPING GLOMERULI lacked a capillary tuft. The site of the tuft was occupied by brightly stained circles and streaks embedded in a less brightly stained matrix (Fig. 2).

TRANSITIONAL GLOMERULI.-Here the concavity of the crescentic tubule incompletely enclosed a small convolution of capillary loops (Fig. 3).

FULLY DEVELOPED GLOMERULI in the kidneys of embryonic, neo-natal, and young rats presented the same general pattern of staining as glomeruli seen in the kidneys of adult rats; in general, however, the capillary tufts of fully developed glomeruli in the young animals showed a simpler pattern of staining than the corresponding structures in adult kidneys.

\section{Cross-Absorption Experiments}

These were based upon the use of the crossabsorbed anti-adult adult rat renal glomerulus $($ F-ARG $\times$ embryo) and anti-adult adult rat splenic 


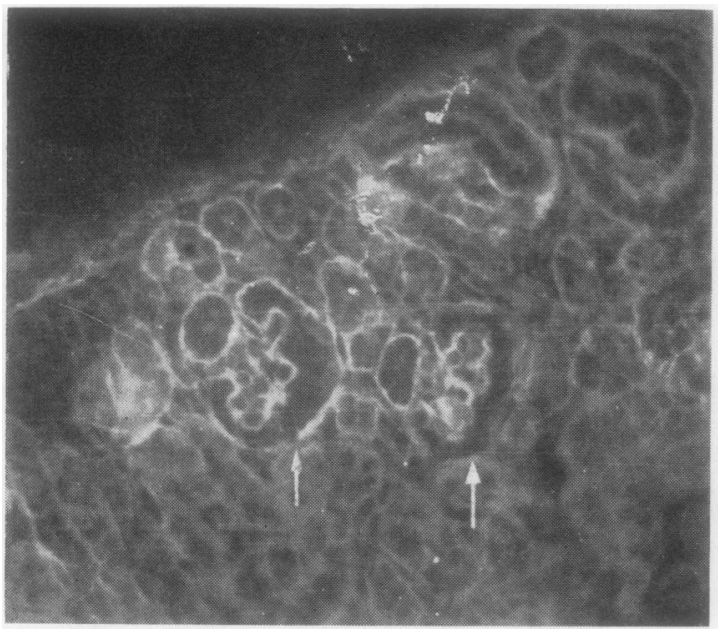

Fig. 2.-Newly developing glomeruli (arrows) in a $3.0 \mathrm{~cm}$. rat embryo kidney section stained with the non-specifically absorbed F-ARG $\times$ human anti-adult rat glomerulus conjugate. The glomeruli take the form of crescentric tubules outlined by a specifically stained membrane. The developing glomerular capillary tufts in the concavity of the tubules show specific staining distributed as circles and streaks. $\times 160$.

reticulum (F-ARS $\times$ embryo) conjugates. The observations made during these experiments are summarized in the Table.

Adult Rats.-The F-ARG $\times$ embryo conjugate was found to have lost little or none of its reactivity for renal glomerular capillaries in the kidneys of adult rats (Fig. 4). Little difference was demonstrable in renal glomerular capillaries stained by the F-ARG $\times$ embryo preparation on the one hand and the F-ARG $\times$ human preparation on the other. Bowman's membranes, however, were stained less brightly by the F-ARG $\times$ embryo conjugate than by the F-ARG $\times$ human conjugate. Similarly the

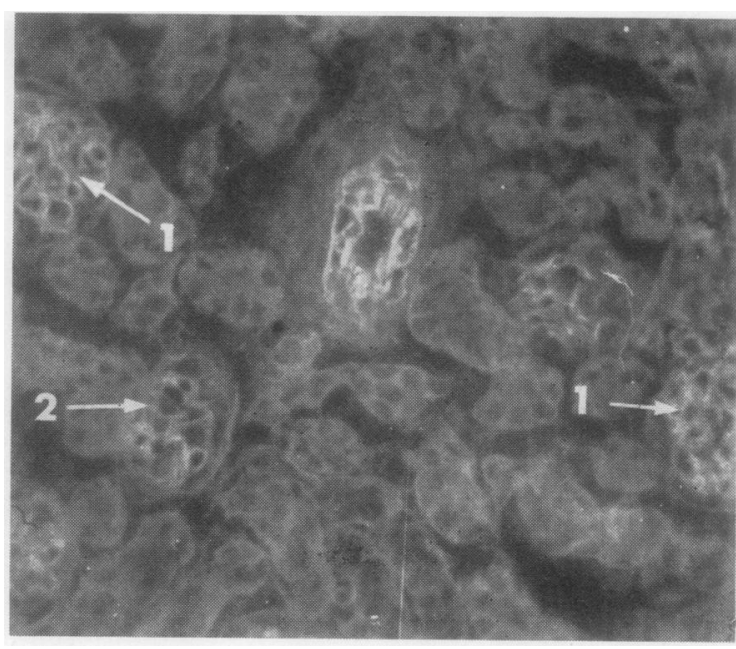

Fig. 3.-Fully developed glomeruli (1) and a transitional glomerulus (2) in a 17-day rat kidney section stained with the cross-absorbed F-ARG $\times$ embryo conjugate. The basement membranes of capillaries in the fully developed and transitional glomeruli show specific staining. $\times 120$.

staining produced by the F-ARG $\times$ embryo conjugate in tubular basement membranes was less bright, and possibly finer, than that produced by the F-ARG $\times$ human conjugate.

The F-ARS $\times$ embryo conjugate was found to have lost almost all of its reactivity for adult renaf tissue. This conjugate produced only faint fluorescence in glomerular capillary tufts and none in the basement membranes of renal tubules in sections from the kidneys of adult rats.

Embryonic, Neo-natal, and Young Rats.-The F-ARG $\times$ embryo conjugate produced specific staining of the basement membranes of crescentic

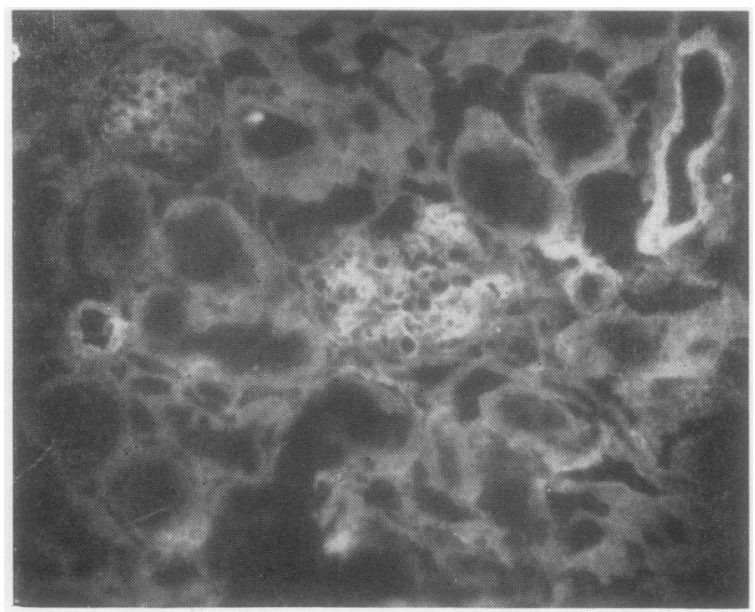

Fig. 4.-Adult rat kidney stained with the F-ARG $\times$ embryo conjugate. Specific staining appears in arterial media and renal glomerular capillary tufts. $\times 120$. 
tubules characterizing incompletely developed glomeruli in the kidneys of embryonic and young rats. This conjugate did not react with capillaries or matrix material of newly developing glomeruli. In F-ARG $\times$ embryo stained sections, specific staining in the position of the glomerular capillary tuft was either absent or distributed solely as streaks.

Cross-absorption of the F-ARG conjugate appeared to effect a varying modification in the reactivity of the conjugate for capillary tufts of transitional glomeruli. The majority of transitional glomeruli, in F-ARG $\times$ embryo stained sections, contained a tuft of weakly stained capillaries (Fig. $3)$; an occasional transitional glomerulus was rendered prominent by virtue of the bright fluorescence of its capillary tuft while other transitional glomeruli were represented by empty cup-shaped capsules.

The staining produced by the F-ARG $\times$ embryo conjugate in fully developed glomeruli did not, in general, differ from that produced by the nonspecifically absorbed conjugate, but in all F-ARG $\times$ embryo stained sections, some glomerular tufts showed an abnormal pattern of staining. In some glomeruli the capillary tuft appeared to be incompletely stained (Fig. 5). In others the position of the capillary tuft appeared to be outlined by a single plicated membrane and occupied by specifically streaky material.

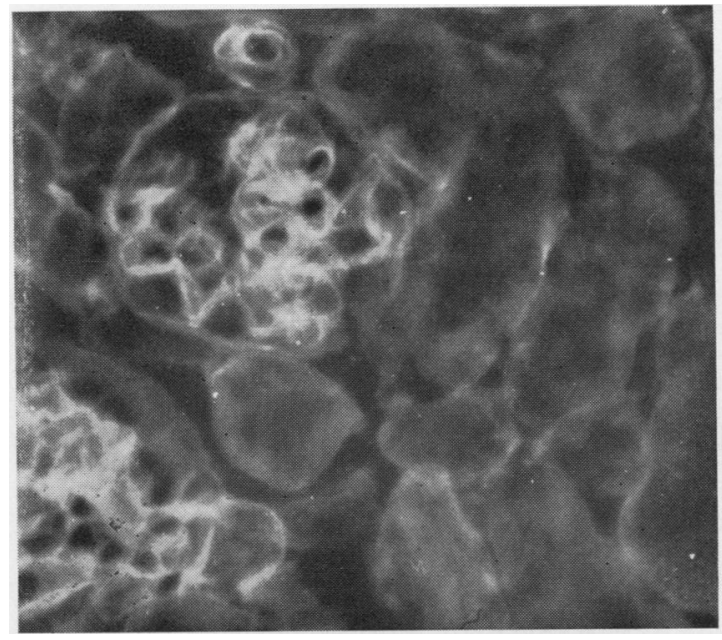

Fig. 5.- Incomplete staining of capillaries in the tuft of a fully developed glomerulus in a 17-day rat kidney section stained with the cross-absorbed F-ARG $\times$ embryo conjugate. $\times 240$.

The F-ARS $\times$ embryo conjugate produced no staining in sections from kidneys of embryonic or neo-natal rats. In sections from older rats the conjugate produced faint fluorescence in the capillaries of fully developed glomeruli, but did not stain the capillary tufts in transitional or newly developing glomeruli.

\section{Discussion}

The present series of experiments was undertaken (a) to determine whether or not the histological differentiation of renal glomeruli was accompanied by changes in their antigenic constitution, and $(b)$ to assess the extent to which any such changes might be attributed to the functional differentiation of renal glomerular capillaries.

The experimental observations are summarized in the Table. It was found that the non-specifically absorbed F-ARG $\times$ human conjugate produced specific staining in the capillaries of fully developed renal glomeruli and in the capillaries of newly developing glomeruli. The cross-absorbed F-ARG $X$ embryo conjugate stained the capillaries of fully developed renal glomeruli, but not those of newly developing glomeruli.

The F-ARS $\times$ human, like the F-ARG $\times$ human conjugate, stained capillaries of mature and of newly developing glomeruli, but the F-ARS $\times$ embryo conjugate produced only faint staining in the capillaries of fully developed glomeruli and none in the capillaries of newly developing glomeruli.

The cross-absorbed reagents represented conjugates which had been absorbed with embryonic connective tissue up to the point where they were found to have lost their ability to produce detectable staining in the dermal mesenchymal tissue of 1.0 $\mathrm{cm}$. rat embryos. Observations arising from the F-ARG $\times$ embryo cross-absorption experiments, therefore, suggest that antigens, reactive with F-ARG antibodies, were present in significantly higher concentrations in the capillaries of mature glomeruli than in the dermal mesenchymal tissue of $1.0 \mathrm{~cm}$. rat embryos, or in the capillaries of newly developing glomeruli.

The F-ARS $\times$ embryo conjugate was found to have lost the greater part of its reactivity for fully developed glomeruli and all of its reactivity for newly developing glomerular capillaries. This finding indicates that the specificity of antibodies in the F-ARS conjugate was directed against antigenic determinants, present in more or less the same concentrations in the capillaries of mature glomeruli, as in embryonic dermal mesenchymal tissue and the capillaries of newly developing glomeruli.

The observations arising from cross-absorption and direct staining experiments raise the possibility that the mature glomerular capillary contains two families of antigenic determinants: one present in higher concentration in the mature glomerular capillary than in embryonic dermal mesenchymal 
tissue; the second present in similar concentrations in each of these two groups of tissue. The former group of glomerular capillary antigens was not detectable in newly developing glomerular capillaries, whereas the latter was detectable.

While the present experiments appear to indicate that alterations in the antigenic constitution of their capillaries accompany the histological differentiation of renal glomeruli, they provide no evidence that these alterations are in any way related to the functional differentiation of glomerular capillaries, as the capillaries of some fully formed glomeruli appeared to lack the mature glomerular capillary antigens. Moreover, these antigens were found as extra-capillary streaks in the capillary tuft of newly developing glomeruli and also in the capillaries of the histologically incompletely developed transitional glomeruli.

\section{Summary}

Fluorescein conjugates prepared from rabbit antiadult rat renal glomerulus and rabbit anti-adult rat splenic reticulum antisera were non-specifically absorbed with human renal connective tissue or cross-absorbed with connective tissues obtained from $1.0 \mathrm{~cm}$. rat embryos. These preparations were applied to sections cut from kidneys of adult, young, neo-natal, and $3.0 \mathrm{~cm}$. embryonic rats. Both of the non-specifically absorbed conjugates stained capillaries of fully developed and incompletely developed glomeruli. The cross-absorbed anti-glomerulus conjugate stained capillaries in fully developed but not in newly developing glomeruli. The cross-absorbed anti-splenic reticulum preparation produced faint capillary staining in fully developed and none in incompletely developed glomeruli.

These observations have been taken to indicate that the histological differentiation of renal glomeruli is accompanied by an alteration in the antigenic constitution of their capillaries.

We wish to thank Mrs. G. Silman for technical assistance and Mr. E. Grinham for the preparation of black and white prints from the original colour transparencies. We are indebted to the Arthritis and Rheumatism Council for financial support.

\section{REFERENCES}

Baxter, J. H., and Goodman, H. C. (1956). J. exp. Med., 104, 467 (Nephrotoxic serum nephritis in rats. 1. Distribution and specificity of the antigen responsible for the production of nephrotoxic antibodies).

Goodman, M., Greenspon, S. A., and Krakower, C. A. (1955). J. Immunol., 75, 96 (Antigenic composition of the various anatomic structures of the canine kidney).
Krakower, C. A., and Greenspon, S. A. (1951). Arch. Path., 51, 629 (Localization of the nephrotoxic antigen within the isolated renal glomerulus). - (1954). Ibid., 58, 401 (Factors leading to variation in concentration of "nephrotoxic" antigen(s) of glomerular basement membrane). (1958). Ibid., 66, 364 (Localization of the "nephrotoxic" antigen(s) in extra-glomerular tissues).

Markowitz, A. S. (1960). Immunology, 3, 117 (Interactions of anti-glomerular basement membrane antisera).

Marshall, J. D., Eveland, W. C., and Smith, C. W. (1958). Proc. Soc. exp. Biol. (N.Y.), 98, 898 (Superiority of fluorescein isothiocyanate (Riggs) for fluorescentantibody technic with a modification of its application).

Rothbard, S., and Watson, R. F. (1961). J. exp. Med., 113, 1041 (Antigenicity of rat collagen. Demonstration of antibody to rat collagen in the renal glomeruli of rats by fluorescence microscopy).

Simonsen, M. (1953). Acta path. microbiol. scand., 32, 85 (Studies on the pathogenesis of experimental glomerulo-nephritis).

Taylor, H. E., Shepherd, W. E., and Robertson, C. E. (1961). Amer. J. Path., 38, 39 (An immunohistochemical examination of granulation tissue with glomerular and lung antiserums).

Altérations de la constitution antigénique des capillaires glomérulaires rénaux accompagnant la maturation histologique des glomérules rénaux chez le rat

\section{RÉSUMÉ}

Des conjugués de fluorescéine préparés à partir de sérums de lapin contenant des anticorps anti-glomerule rénal de rat adulte et anti-réticulum splénique de rat adulte furent absorbés d'une façon non spécifique avec du tissu conjonctif de rein humain ou "cross-absorbé" avec des tissues conjonctifs obtenus à partir d'embryon de rat d'un $\mathrm{cm}$. de long. Ces préparations furent mises en présence de sections de rein de rat adulte, jeune, nouveau-né et embryonnaire de $3 \mathrm{~cm}$. Les deux types de conjugués absorbés de façon non spécifique colorèrent les capillaires de tous les glomérules, complètement et incomplètement développés. Le conjugué anti-glomérule "cross-absorbé" colora les capillaires des glomérules complètement développés mais non pas ceux des glomérules aux stades initiaux de leur développement. La préparation antiréticulum splénique "cross-absorbée" donna une faible coloration des capillaires dans les glomérules complètement développés et aucune dans les glomérules immatures.

Ces observations ont été recueillies pour montrer que la différentiation histologique des glomérules rénaux est accompagnée par une altération de la constitution antigénique de leur capillaires.

Alteraciones de la constitución antigénica de los capilares del glomérulo renal que acompañan la maduración histológica del glomérulo renal en la rata

SUMARIO

Conjugados de fuoresceina preparados a partir de sueros del conejo conteniendo anticuerpos anti-glomérulo 
renal de rata adulta y anti-retículo esplénico de rata adulta fueron absorbidos de una manera no específica con tejido conectivo de riñon humano o absorbidos de manera cruzada con tejido conectivo obtenido a partir de un embrion de rata de un $\mathrm{cm}$. de longitud. Estas preparaciones fueron aplicadas a cortes de riñon de rata adulta, jóven, neonatal y embrionario de $3 \mathrm{~cm}$. Ambos tipos de conjugados absorbidos de manera no específica tiñeron los capilares de todos los glomérulos, tanto completa como incomplétamente desarrollados. El conjugado anti-glomérulo absorbido de manera cruzada tiñó los capilares de los glomérulos completamente desarrollados pero no los de los glomérulos que estaban en periodo inicial de desarrollo. La preparación contra el retículo esplénico absorbida de manera cruzada tiño debilmente los capilares de los glomérulos completamente desarrollados pero no los de los inmaduros.

Se recogieron estas observaciones par indicar que la diferenciación histológica de los glomérulos renales se acompaña de una alteración en la constitución antigénica de sus capilares. 